Shamayim: Jurnal Teologi dan Pendidikan Kristiani

Volume 1, Nomor 1, 2020 (78-91)

http://hologos.college/ejournal/index.php/shamayim/index

\title{
Studi Kecerdasan Visual-Spasial Pada Anak Usia 5-6 Tahun Melalui Sentra Balok
}

\author{
Sartika Pa'indu \\ Sekolah Tinggi Agama Kristen Terpadu-PESAT \\ Sartikapaindu9@gmail.com \\ Rida Sinaga \\ Sekolah Tinggi Agama Kristen Terpadu-PESAT \\ ridasinagabonor@gmail.com \\ Frets Keriapy \\ Sekolah Tinggi Agama Kristen Terpadu-PESAT \\ Fretskeriapy1106@gmail.com
}

\begin{abstract}
Early Childhood Education (PAUD), can be used to explore children's intelligence. One of them is visual-spatial intelligence. Visual-spatial intelligence is important for children because visual-spatial intelligence enables children to learn visually and generate ideas. Children can think in concept (holistically) to understand something. To develop visual-spatial intelligence in children, the center block is one of the tools that can be used to develop it. Through the block center children can be taught to recognize the shape, color and size of the blocks. Block center was chosen because children love building designing games. Through designing and constructing a building such as a house, palace and other forms, it is hoped that the visual-spatial intelligence of children can develop. The method used in this research is the library research method, namely the form of research carried out through research report books, journals and other documents. In the beam center there are various geometric shapes in various sizes, some are colored and some are plain. In playing blocks, there are eleven stages, from simple to complex building. To be able to make children creative, teachers need to provide adequate support, opportunities, times, and facilities. The results of research on block center can be said to improve visualspatial intelligence. Because the block center contributes to the improvement of visualspatial intelligence. It can be seen from the conclusions of the research results that when children play in a block center with adequate support, opportunity, time, and facilities provided by the teacher to children, it can improve children's visual-spatial intelligence with the characteristics of a visually-spatial intelligent child having advantages. such as:
\end{abstract}


children quickly understand the explanation from the teacher related to the building to be made, children can do more than the teacher's orders, children can mix colors well, children build beautifully, neatly and vary and children enjoy doing and enjoying playing blocks.

Key words: Visual-Spatial Intelligence, Block Center, Teacher

\begin{abstract}
Abstrak
Pendidikan Anak Usia Dini (PAUD), dapat digunakan untuk menggali kecerdasan yang dimiliki anak. Salah satunya adalah kecerdasan visual-spasial. Kecerdasan visualspasial penting dimiliki anak karena kecerdasan visual- spasial membuat anak dapat belajar secara visual dan memunculkan ide-ide. Anak dapat berfikir secara konsep (holistik) untuk memahami sesuatu. Untuk mengembangkan kecerdasan visual-spasial pada anak, sentra balok merupakan salah satu sarana yang dapat digunakan untuk mengembangkannya. Melalui sentra balok anak dapat diajarkan mengenal bentuk, warna serta ukuran dari balok tersebut. Sentra balok dipilih karena anak-anak menyukai permainan merancang bangunan. Melalui merancang dan membangun sebuah bangunan seperti rumah, istana dan bentuk lainnya diharapkan dapat mengembangkan kecerdasan visual-spasial pada anak. Metode yang digunakan dalam penelitian ini adalah metode penelitian kepustakaan yaitu bentuk penelitian yang dilakukan melalui buku laporan penelitian, jurnal Di sentra balok terdapat berbagai bentuk geometri dalam berbagai ukuran ada yang berwarna dan ada yang polos. Dalam bermain balok ada sebelas tahapan, mulai dari sederhana sampai membangun secara komplek. Untuk dapat membuat anak menjadi kreatif maka guru perlu memberikan dukungan, kesempatan, waktu, serta sarana yang memadai. Hasil penelitian mengenai sentra balok dapat dikatakan meningkatkan kecerdasan visual-spasial. Karena sentra balok memberikan kontribusi terhadap peningkatan kecerdasan visual-spasial. Dapat dilihat dari kesimpulan hasil penelitian bahwa pada saat anak bermain di sentra balok dengan dukungan, kesempatan, waktu, serta sarana yang memadai yang diberikan guru kepada anak dapat meningkatkan kecerdasan visual-spasial anak dengan ciri-ciri anak yang cerdas secara visual-spasial memiliki kelebihan seperti : anak cepat memahami penjelasan dari guru yang berhubungan dengan bangunan yang akan dibuat, anak dapat melakukan lebih dari perintah guru, anak dapat memadukan warna dengan baik, anak membangun dengan indah, rapi dan bervariasi dan anak senang melakukan serta menikmati bermain balok.
\end{abstract}

Kata kunci: Kecerdasan Visual-Spasial, Sentra Balok, Guru

\title{
Pendahuluan
}

Setiap manusia diciptakan dengan keunikan/ ciri khas masing-masing seperti berkulit putih, hitam, tinggi, pendek, rambut lurus dan keriting. Menurut KBBI manusia 
adalah makhluk yang berakal budi (mampu menguasai makhluk lain). ${ }^{1}$ Hal serupa pun dikatakan oleh Suprihatin bersama Rosita dengan mengutip Montesori bahwa anak ciptakan secara unik dan mereka bukanlah sebuah miniatur yang bisa dipakai oleh orangtua maupun guru. ${ }^{2}$ Tuhan memperlengkapi manusia sebagai makhluk yang berakal budi untuk dapat membedakannya dengan makhluk hidup lain. Adanya akal budi juga menyebabkan manusia mampu berpikir abstrak dan konseptual sehingga manusia disebut sebagai makhluk pemikir/ berakal budi. Dengan akal manusia dapat membedakan yang baik maupun yang buruk. Untuk dapat mengembangkan akal tersebut manusia membutuhkan yang namanya pendidikan.

Pendidikan adalah segala kegiatan pembelajaran yang berlangsung sepanjang zaman dalam segala situasi kegiatan kehidupan. ${ }^{3}$ Selanjutnya, Pendidikan pun harusnya dapat mengubah kehidupan baik dia sebagai guru (pendidik) maupun murid (nara-didik). ${ }^{4}$ Hal serupa pun dikatakan oleh Romini bersama Ida Destariana Harefa bahwa lingkungan di mana anak itu berada memengaruhi dan dapat menjadi proses pendidikan. ${ }^{5}$ Dalam arti luas pada dasarnya pendidikan adalah wajib bagi siapa saja, kapan saja, dan di mana saja, karena menjadi dewasa, cerdas, dan matang adalah hak asasi manusia pada umumnya. ${ }^{6}$ Pendidikan penting untuk diterapkan sejak usia dini.

Menurut Undang-Undang Republik Indonesia Nomor 20 tahun 2003 tentang Sistem Pendidikan Nasional pada pasal 1 ayat 14 menyatakan bahwa pendidikan anak usia dini adalah suatu upaya pembinaan yang ditujukan kepada anak sejak lahir sampai dengan usia enam tahun yang dilakukan melalui pemberian rangsangan pendidikan untuk membantu pertumbuhan dan perkembangan jasmani dan rohani agar anak memiliki kesiapan dalam memasuki pendidikan lebih lanjut (Depdiknas, 2003). ${ }^{7}$

Melalui Pendidikan kecerdasan majemuk yang dimiliki anak dapat dikembangkan. Howard Gardner mengemukakan ada sembilan kecerdasan yaitu, kecerdasan musikal, kecerdasan kinestetik, kecerdasan logis-matematis, kecerdasan verbal-linguistik, kecerdasan visual-spasial, kecerdasan interpersonal, kecerdasan intrapersonal, kecerdasan

\footnotetext{
${ }^{1}$ Kamus Besar Bahasa Indonesia and Mengenal Operasional Perbankan, "Jakarta: Penerbit PT Gramedia Pustaka Utama” (2014): 629.

${ }^{2}$ Eny Suprihatin and Desti Rosita, "PENERAPAN TEKNIK SCAFFOLDING SEBAGAI UPAYA MENINGKATKAN KEMANDIRIAN BELAJAR ANAK USIA 5-6 TAHUN DI TK KRISTEN KADASITURU TERPADU," EDULEAD: Journal of Christian Education and Leadership 1, no. 1 (2020): 34-55.

${ }^{3}$ Suparlan Suhartono, Filsafat Pendidikan (Jogjakarta, 2007), 80.

4 Frets Keriapy, "Pendidikan Kristiani Transformatif Berbasis Multikultural Dalam Konteks Indonesia," REGULA FIDEI: Jurnal Pendidikan Agama Kristen 5, no. 2 (2020): 82-93.

5 Romini Romini and Ida Destariana Harefa, "MANFAAT PENGGUNAAN ALKITAB BERGAMBAR TERHADAP PERKEMBANGAN KEROHANIAN ANAK FUTURE CENTER USIA 7-9 TAHUN DI BULUH AWAR," EDULEAD: Journal of Christian Education and Leadership 1, no. 1 (2020): $1-14$.

${ }^{6}$ Suparlan Suhartono, Filsafat Pendidikan.

${ }^{7}$ Siti Aisyah and others, "Perkembangan Dan Konsep Dasar Pengembangan Anak Usia Dini," Jakarta: universitas terbuka (2008): 1.3.
} 
naturalis dan kecerdasan eksistensial. Berikut penjelasan dari masing-masing kecerdasan tersebut. Kecerdasan musikal, merupakan kemampuan seseorang yang peka terhadap suara-suara nonverbal yang berada di lingkungan sekelilingnya, termasuk dalam hal ini adalah nada dan ritme. Selanjutnya kecerdasan kinestetik, merupakan kemampuan seseorang untuk secara aktif menggunakan bagian-bagian atau seluruh tubuhnya untuk berkomunikasi dan memecahkan berbagai masalah. ${ }^{8}$

Kemudian kecerdasan logis-matematis yang merupakan kemampuan seseorang dalam berpikir secara edukatif dan deduktif, berpikir menurut aturan logika, memahami, dan menganalisis, pola angka-angka, serta memecahkan masalah dengan menggunakan kemampuan berpikir. Berikutnya kecerdasan verbal-linguistik, yaitu kemampuan untuk menggunakan bahasa dan kata-kata, baik secara tertulis maupun lisan, dalam berbagai bentuk yang berbeda untuk mengekspresikan gagasan-gagasannya. ${ }^{9}$ Kemudian kecerdasan interpersonal, merupakan kemampuan seseorang untuk peka terhadap perasaan orang lain. Sedangkan kecerdasan intrapersonal, merupakan kemampuan seseorang untuk peka terhadap perasaan dirinya sendiri, dan cenderung mampu mengenali kekuatan maupun kelemahan yang ada pada dirinya. ${ }^{10}$

Berikutnya kecerdasan naturalistik merupakan kemampuan seseorang utuk peka terhadap lingkungan alam, senang berada di lingkungan alam yang terbuka seperti pantai, gunung, cagar alam, dan hutan. Kemudian kecerdasan eksistensial merupakan kemampuan untuk menempatkan diri dalam lingkup kosmos terjauh dengan makna hidup, makna kematian, nasib dunia, jasmani maupun kewajiban, dan dengan makna pengalaman mendalam, seperti cinta dan kesenian. ${ }^{11}$ Dan yang terakhir yang juga di bahas dalam penelitian ini yaitu kecerdasan visual-spasial yang merupakan salah satu dari beberapa jenis kecerdasan yang berkaitan dengan kemampuan seseorang dalam melihat hubungan antar bentuk dan hubungan sesuatu dalam ruang. ${ }^{12}$

Amstrong mengatakan bahwa setiap anak memiliki kapasitas untuk memiliki sembilan kecerdasan. Kecerdasan-kecerdasan tersebut ada yang dapat sangat berkembang, cukup berkembang, dan kurang berkembang. ${ }^{13}$ Tetapi dalam penelitian ini peneliti hanya fokus untuk mengkaji lebih mendalam tentang kecerdasan visual-spasial anak. Kecerdasan visual-spasial adalah kecerdasan yang berkaitan dengan kemampuan anak dalam memvisualisasikan gambar di dalam pikirannya atau kemampuan anak berpikir dalam

8 Winda Gunarti, Lilis Suryani, and Azizah Muis, "Metode Pengembangan Perilaku Dan Kemampuan Dasar Anak Usia Dini," Jakarta: Universitas Terbuka (2008): 2.24-2.25.

${ }^{9}$ Gunarti, Suryani, and Muis, "Metode Pengembangan Perilaku Dan Kemampuan Dasar Anak Usia Dini.”

10 Ibid.

11 Ibid.

73.

${ }^{12}$ Deasy Harianti, Metode Jitu Meningkatkan Daya Ingat (Memory Power) (Tangga Pustaka, 2008),

13 Tadkiroatun Musfiroh, "Hakikat Kecerdasan Majemuk (Multiple Intelligences)," Modul Perkuliahan pdf, Universitas Terbuka (2014): 1.5. 
bentuk visual untuk memecahkan suatu masalah atau menemukan jawaban. ${ }^{14}$ Kecerdasan visual-spasial juga dapat diartikan sebagai kemampuan yang berkaitan dengan memadukan ciri-ciri objek atau benda yang ada di lingkungan sekitar dalam bentuk gambar mental yang dapat diungkapkan kembali dalam bentuk informasi rinci, gambar, lukisan, pahatan dan lain-lain. Kecerdasan ini melibatkan kepekaan terhadap warna, garis, bentuk, ukuran, luas dan hubungan antara unsur-unsur tersebut. ${ }^{15}$ Kecerdasan visual-spasial adalah kecerdasan yang berkaitan dengan kemampuan anak dalam memvisualisasikan gambar di dalam pikiran seseorang atau kemampuan anak berpikir dalam bentuk visual untuk memecahkan suatu masalah atau menemukan jawaban. ${ }^{16}$

Selanjutnya dalam buku Redi Awal Maulana, mendefinisikan kecerdasan visualspasial sebagai kemampuan anak dalam memvisualisasikan apa yang ada dalam benaknya melalui gambar, susunan balok, atau penjelasan yang sangat rinci misalnya mengenai rute ke sekolah. ${ }^{17} \mathrm{Hal}$ serupa pun dijelaskan oleh Simanjuntak dengan mendefinisikan kecerdasan visual-spasial sebagai bentuk keahlian yang dapat membedakan secara visual, mengenai bentuk, warna, gambaran mental, dan manipulasi-duplikasi gambar. ${ }^{18}$

Jadi kecerdasan visual-spasial adalah keahlian yang dimiliki seseorang untuk dapat membedakan bentuk, menyusun puzzle, memiliki kepekaan terhadap warna, garis-garis, bentuk-bentuk, dan bangunan-bangunan. Bangunan yang dirancang arsitektur, desain taman, lukisan, rancangan busana, pahatan bahkan benda-benda sehari-hari yang dipakai manusia pun merupakan hasil dari karya orang yang memiliki kecerdasan visual-spasial. Memvisualisasikan apa yang ada dalam pikirannya melalui gambar, susunan balok, atau penjelasan yang sangat rinci misalnya mengenai rute ke sekolah. Musfiroh mengatakan bahwa hal yang dapat dilakukan guru untuk merangsang kecerdasan visual-spasial pada anak yaitu dapat dilakukan dengan beberapa cara di antaranya memberikan anak kesempatan untuk melukis, menyusun puzzle, bermain plastisin dengan cara membentuk sesuatu. Agar daya imajinasi anak dapat dikembangkan dengan baik maka guru perlu memfasilitasi anak dengan cara menyiapkan alat-alat permainan konstruktif seperti lego, puzzle, balok berbentuk geometr, lasie dan peralatan untuk menggambar. ${ }^{19}$

Jadi untuk mengembangkan kecerdasan visual-spasial pada anak, sentra balok merupakan salah satu sarana yang dapat digunakan untuk mengembangkannya. Sentra balok adalah area atau zona bermain anak yang di dalamnya terdapat berbagai macam bentuk balok dan aksesorisnya serta kegiatan pembelajarannya menggunakan empat pijakan main. ${ }^{20}$.

\footnotetext{
${ }^{14}$ Susianty Selaras Ndari and Chandrawaty Chandrawaty, "Telaah Kurikulum Pendidikan Anak Usia Dini” (Edu Publisher, n.d.), 195.

${ }^{15}$ Martini Jamaris, "Pengukuran Kecerdasan Jamak," Bogor: Ghalia Indonesia (2017): 5.

${ }^{16}$ Ndari and Chandrawaty, "Telaah Kurikulum Pendidikan Anak Usia Dini."

${ }^{17}$ Redi Awal Maulana, Anak Usia Dini Math: Untuk PAUD, vol. 1 (IGI PD. Sumedang, 2019), 40.

${ }^{18}$ P.N.H Simanjutak, Pendidikan Kewarganegaraan (Jakarta, 2017), 90.

19 Tadkiroatun Musfiroh, "Bermain Sambil Belajar Dan Mengasah Kecerdasan," Jakarta: Depdiknas (2005): 310.

${ }^{20}$ Nini Aryani et al., MANAJEMEN PEMBELAJARAN PAUD: Berbasis Perkembangan Anak (EDU PUBLISHER, 2020), 31.
} 


\section{Metode Penelitian}

Jenis metode yang digunakan dalam penelitian ini adalah metode penelitian kepustakaan. Penelitian kepustakaan adalah penelitian yang identik dengan kegiatan analisis teks atau wacana yang menyelidiki suatu peristiwa, baik berupa perbuatan atau tulisan yang diteliti untuk mendapatkan fakta-fakta yang tepat (menemukan asal-usul, sebab dan penyebab sebenarnya). ${ }^{21}$ Menurut Zed studi kepustakaan adalah bentuk penelitian di mana peneliti berhadapan langsung dengan data dan angka bukan langsung dari lapangan atau saksi mata dan data pustaka bersifat siap pakai. ${ }^{22}$ Metode pengumpulan data yang akan digunakan dalam penelitian ini yaitu metode studi kepustakaan yaitu dengan cara meneliti dan memahami buku-buku, dokumen sdan jurnal-jurnal yang sudah diterbitkan yang berkaitan dengan studi kasus yang diteliti oleh peneliti.

\section{Pembahasan dan Hasil}

Bermain adalah suatu kegiatan yang dilakukan dengan atau tanpa mempergunakan alat yang menghasilkan pengertian atau memberikan informasi, memberi kesenangan maupun mengembangkan imajinasi pada anak. ${ }^{23}$ Dunia belajar anak yaitu pada saat anak bermain. Memberikan kesempatan kepada anak untuk bermain yang lebih banyak akan meningkatkan pemahaman anak tentang konsep maupun pengertian dasar suatu pengetahuan serta memberikan kesempatan kepada anak untuk bereksplorasi.

Montessori, seorang tokoh pendidikan menekankan bahwa ketika anak bermain, ia akan mempelajari dan menyerap segala sesuatu yang terjadi di lingkungan sekitarnya. Untuk itu, perencanaan dan persiapan lingkungan belajar anak harus dirancang dengan seksama sehingga segala sesuatu dapat memberikan kesempatan belajar yang menyenangkan bagi anak. ${ }^{24}$ Dalam dunia pendidikan agar cara bermain anak dapat terorganisir dengan rapi, teratur, menyenangkan, sistematis serta kreatif salah satu sarana bermain anak yang dapat digunakan yaitu dengan menata ruangan dalam bentuk sentrasentra. Dengan menggunakan metode sentra, pengetahuan dan keterampilan anak diorganisir secara rapi sesuai dengan tahap perkembangan anak. Sentra merupakan zona atau area main anak yang dilengkapi dengan berbagai perangkat alat main yang berfungsi sebagai pijakan lingkungan yang diperlukan untuk mendukung perkembangan anak usia dini, yang tercakup dalam tiga jenis main, yaitu main sensorimotor, main peran, dan main pembangunan. ${ }^{25}$ Berikut penjelasan ketiga ragam main tersebut:

\footnotetext{
${ }^{21}$ A Hamzah, "Metode Penelitian Kepustakaan Library Research Kajian Filosofis, Aplikasi, Proses, Dan Hasil Penelitian," Literasi Nusantara (2020): 7.

${ }^{22}$ Hamzah, "Metode Penelitian Kepustakaan Library Research Kajian Filosofis, Aplikasi, Proses, Dan Hasil Penelitian."

23 Anggani Sudono, Sumber Belajar Dan Alat Permainan Untuk Pendidikan Anak Usia Dini (Grasindo, 2000), 1.

${ }^{24}$ Sudono, Sumber Belajar Dan Alat Permainan Untuk Pendidikan Anak Usia Dini.

${ }^{25}$ M Zakaria Hanafi, Implementasi Metode Sentra Dalam Pengembangan Kecerdasan Majemuk Anak Usia Dini (Deepublish, 2019), 79.
} 
a. Main sensorimotor (fungsional) pada anak usia dini merupakan stimulus untuk mendukung proses kerja otak manusia dalam mengelola informasi yang didapatkan anak dari lingkungan saat bermain, baik bermain dengan tubuhnya sendiri maupun bermain dengan berbagai benda di sekitarnya. ${ }^{26}$ Main sensorimotor lebih menekankan kepada penguasaan panca indera (pendengaran, penglihatan, perasa, penciuman dan peraba) untuk mengenali lingkungannya.

b. Main peran (simbolik) yaitu anak berpura-pura menjadi orang lain, meniru perbuatan atau perkataan orang, mengambil peran dan menggunakan alat-alat riil atau imajinasi. Menurut Erik Erikson ada dua jenis main peran yaitu main peran besar (anak bermain dengan menjadi tokoh menggunakan alat yang sesungguhnya), misalnya peran menjadi dokter, polisi serta nelayan. Anak akan menggunakan pakaian sesuai dengan profesi yang akan diperankan, dan main peran kecil (anak membuat cerita dan memainkan peran menggunakan alat yang berukuran kecil). Misalnya, boneka dan wayang. ${ }^{27}$

c. Main pembangunan yaitu anak bermain dengan benda untuk mewujudkan ide/gagasan yang dibangun dalam pikirannya menjadi sesuatu bentuk nyata. ${ }^{28}$ Benda yang digunakan terbagi atas dua bagian yaitu benda padat dan benda cair. Yang termasuk benda padat yaitu balok, lego, puzzle, bristle block, Lincoln logs dan barang daur ulang. Sedangkan benda cair yaitu air, pasir, finger paint, lumpur, tanah liat, plastisin, krayon, melukis, pen, dan pensil. ${ }^{29}$

Melalui sentra, seluruh kegiatan bermain distimulus untuk mengasah kecerdasan majemuk dan keterampilan anak dalam suasana nyaman dan menyenangkan. Seluruh kegiatan pembelajaran di sentra, berpusat pada anak sebagai subyek pembelajar, sedangkan guru sebagai motivator dan fasilitator. Anak sebagai subyek dalam proses pembelajaran dapat mengembangkan potensi kecerdasan anak secara optimal dan membantu anak tumbuh menjadi semakin aktif dan kreatif. Ada tujuh sentra yang dapat digunakan untuk mengembangkan kecerdasan majemuk anak yaitu sentra bahan alam, seni, balok, persiapan, agama, main peran dan memasak. Sentra balok merupakan tempat bermain sambil belajar untuk mempresentasikan ide ke dalam bentuk nyata (bangunan). ${ }^{30}$

Jadi sentra balok adalah tempat anak berkreasi sesuai dengan imajinasinya dengan menggunakan balok. Bermain balok juga merupakan suatu kegiatan yang banyak memberikan manfaat bagi perkembangan anak. Kegiatan bermain balok dapat digunakan untuk mengenalkan konsep pembelajaran seperti mengenal bentuk dan warna, dengan bermain balok anak akan lebih mudah mengingat hal-hal yang dipelajari karena dilakukan

\footnotetext{
${ }^{26}$ Hanafi, Implementasi Metode Sentra Dalam Pengembangan Kecerdasan Majemuk Anak Usia Dini.

${ }^{27}$ Ibid.

${ }^{28}$ Djoko Adi Walujo and Anies Listyowati, Kompendium PAUD: Memahami PAUD Secara Singkat (Kencana, 2016), 53.

${ }^{29}$ Herminayu and Bambang Suteng Sulasmono, Modul Pelatihan Model Pembelajaran BCCT (Salatiga: UKSW, 2020), 31.

${ }^{30}$ Dadan Suryana, Pendidikan Anak Usia Dini: Stimulasi \& Aspek Perkembangan Anak (Prenada Media, 2016), 126.
} 
sesuai dengan imajinasi anak. Selain itu melalui sentra ini anak dapat belajar konsep matematika seperti ukuran, bentuk, jumlah dan angka. Dengan cara anak dapat mengurutkan benda berdasarkan ukuran, warna dan bentuk serta mengelompokkan balok sesuai dengan jenis-jenis balok.

Dengan adanya sarana yang memadai dapat membuat anak semakin kreatif dalam melaksanakan pembelajaran serta bangunan yang dibuat anak semakin bervariasi. Untuk dapat membuat anak menjadi kreatif dan mengembangkan kecerdasan majemuk pada anak guru perlu memberikan dukungan, kesempatan, waktu, serta sarana yang memadai. Alat dan bahan yang perlu disiapkan oleh guru yaitu: jumlah balok yang disediakan untuk tiap anak minimal 100 balok, 200 balok atau lebih dengan kelompok warna natural dari berbagai bentuk dan ukuran. ${ }^{31}$

Kemudian aksesoris balok, alas berbentuk geometri dan berwarna. Dan keranjang kecil untuk menaruh balok pada saat diambil dan dikembalikan. Di sentra balok, anak berperan sebagai arsitek atau desainer interior. Misalnya, saat membangun rumah dari balok, otak anak akan berpikir dan mengeksplorasi imajinasinya. Wismiarti mengatakan bahwa setelah memikirkan tentang bangunan yang dibuat, anak akan mengorganisasikan dan memanipulasi ruangan-ruangannya, bagaimana akan disusun sesuai kebutuhan. ${ }^{32}$

Cara meningkatkan kecerdasan visual-spasial melalui sentra balok yaitu pertama, guru mengenalkan bentuk-bentuk balok serta ukuran besar/kecil balok. Kedua guru memberikan contoh pada bangunan yang komplit atau membangun sebuah bangunan beserta ruangannya dalam bentuk gambar. Ketiga anak menuangkan dalam bentuk gambar bangunan yang telah dibuatnya sesuai dengan imajinasinya. ${ }^{33}$

Dengan ini guru dapat menemukan anak yang cerdas secara visual-spasial dengan cara mengamati anak pada saat bermain di sentra balok. Anak yang cerdas secara visualspasial memiliki kelebihan seperti anak cepat memahami penjelasan dari guru yang berhubungan dengan bangunan yang akan dibuat, anak dapat melakukan lebih dari perintah guru, anak dapat memadukan warna dengan baik, anak membangun dengan indah, rapi dan bervariasi, anak senang melakukan serta menikmati bermain.

Bermain di sentra balok memiliki tahapan-tahapan. Anak tidak bisa dipaksa untuk langsung membangun bangunan yang diperintahkan oleh guru, tetapi anak akan mengikuti tahapan-tahapan di sentra balok secara sistematis. Guru dapat mengetahui peningkatan anak melalui observasi dan dokumentasi yang dilakukan oleh guru.

${ }^{31}$ Riskia Fitriani and Rohita Rohita, "Penanaman Kemandirian Anak Melalui Pembelajaran Di Sentra Balok," Jurnal Al-Azhar Indonesia Seri Humaniora 5, no. 1 (2019): 1-9.

32 Rhenald Kasali, Sentra: Membangun Kecerdasan Dan Kemampuan Anak Sejak Usia Dini, Demi Masa Depan Yang Cemerlang (Mizan, 2019), 198.

${ }^{33}$ Wahyuni and Ratna Wahyu Pusari, , Upaya Meningkatkan Kemampuan Visual-Spasial Anak Melalui Bermain Di Sentra Balok Pada Kelompok A TK Himawari Semarang (Semarang: Universitas PGRI, 2015), 95-107. 
Berikut beberapa tahap saat anak bermain balok: ${ }^{34}$

1. Anak hanya membawa atau memindahkan balok dari satu tempat ke tempat lain dengan tangan telanjang atau keranjang. Pada tahap ini anak juga mulai tertarik untuk mengenal balok.

2. Anak mulai menyusun balok di lantai, baik secara memanjang atau menumpuknya hingga tinggi seperti menara. Pada tahap ini anak mulai berimajinasi bahwa susunan balok di lantai dijadikan jalan yang bisa dilewati oleh kendaraan.

3. Anak membangun dengan cara, menggabungkan tumpukan-tumpukan balok atau menumpuk garis demi garis.

4. Anak menempatkan dua balok sejajar yang berjarak dan menghubungkan diantara dua balok dengan satu balok di atasnya, membentuk lengkungan atau jembatan.

5. Anak membuat bentuk seperti kotak terbuka dari empat atau lebih balok-balok.

6. Anak membuat atap pada bangunan seperti kotak yang terbuka, menjadi ruang tertutup tiga dimensi.

7. Anak menggabungkan/ mengkombinasikan beberapa bentuk bangunan tetapi belum diberi nama.

8. Anak membangun satu bangunan dan memberi nama pada balok satu-satu sebagai benda. Walaupun bangunan tersebut tidak seperti benda yang di maksud tetapi mewakili pikiran anak.

9. Anak memberi nama pada seluruh bangunan balok sebagai satu benda, satu bangunan mempresentasikan satu benda.

10. Anak membangun bangunan tertutup yang mempresentasikan ruang dalam dan ruang luar. Obyek-obyek di dalam dan di luar dipisahkan secara tepat.

11. Anak membangun secara rumit, terdiri dari ruang dalam, luar, jalan dan pengertian skala.

Menurut Iva Noorlaila dalam Puput, mengatakan bahwa pijakan dalam sentra untuk mendukung perkembangan anak antara lain: ${ }^{35}$

a. Pijakan lingkungan main yaitu pendidik menyiapkan serta menata alat dan bahan main sesuai dengan rencana dan jadwal kegiatan yang telah disusun.

b. Pijakan sebelum main yaitu guru dan anak melingkar, pendidik memberi salam dan menanyakan kabar anak-anak, mengabsen dan meminta anak secara bergilir untuk memimpin doa. Selanjutnya guru menyampaikan tema hari itu dan mengaitkan dengan kehidupan anak. Guru membacakan cerita dan menanyakan pesan dari cerita itu. Kemudian guru menyampaikan aturan main dan mempersilahkan anak bermain.

c. Pijakan saat main yaitu guru berkeliling di antara anak-anak yang sedang bermain, dan memberi dukungan dengan pertanyaan yang positif yang ada kaitannya dengan pekerjaan yang dilakukan anak, memberi bantuan jika dibutuhkan, mencatat apa yang (n.d.).

34 “Kb Tkwonorejo.Khadijah.or.Id/Sentra-Balok/ Diakses Tanggal 30 Juli 2020, Pukul 07.11.” 35 PUPUT HANA PERTIWI and UBAIDILLAH KHASAN, "IMPLEMENTASI PEMBELAJARAN SENTRA BALOK DALAM PENGEMBANGAN MOTORIK HALUS ANAK USIA 45 TAHUN DI TK AISYIYAH PUCANGAN 1 KARTASURA TAHUN AJARAN 2019/2020" (IAIN SURAKARTA, 2020), 27. 
dilakukan anak baik jenis main dan tahap perkembangannya, mengumpulkan hasil kerja anak serta memberikan instruksi untuk bersiap-siap menyelesaikan kegiatannya bila waktu tinggal 5 menit.

d. Pijakan setelah main yaitu guru dan anak membereskan mainan, setelah itu anak kembali duduk dalam lingkaran dan guru menanyakan kepada setiap kegiatan main yang dilakukan guna melatih daya ingat anak dan melatih anak mengemukakan gagasan dan pengalaman mainnya (perbendaharaan kata anak). Demikianlah pelaksanaan proses belajar mengajar di sentra balok.

Dari teori di atas dapat disimpulkan bahwa kecerdasan visual-spasial dapat dikembangkan melalui sentra balok dengan memfasilitasi anak untuk dapat mengembangkan imajinasinya serta menuangkannya dalam bentuk bangunan yang dapat dilihat secara visual, dan anak semakin kreatif serta mampu memecahkan masalahnya. Anak akan membangun secara rumit, terdiri dari ruang dalam, luar, jalan dan pengertian skala. Kecerdasan visual-spasial pada anak yang dapat berkembang di sentra balok yaitu anak dapat dilatih menjadi arsitek, desainer, dan pelukis.

\section{Sentra Balok}

Sentra balok merupakan tempat bermain sambil belajar untuk mempresentasikan ide ke dalam bentuk nyata (bangunan). ${ }^{36}$ Agar pembelajaran dapat terlaksana secara sistematis, maka guru hendaknya mengikuti pijakan-pijakan yang terdiri dari empat bagian yaitu pertama, pijakan lingkungan main yaitu guru menata ruangan sesuai dengan kapasitas dan keragaman jenis permainan. kedua, pijakan sebelum bermain yaitu guru dan anak duduk melingkar, berdoa bersama, mendengarkan cerita, guru menyampaikan jenis mainan yang ada dan aturan bermain. ketiga, pijakan saat bermain, guru mencatat perilaku, kemampuan peserta didik, guru membantu peserta didik jika dibutuhkan, dan guru mengingatkan peserta didik bila ada yang melanggar aturan. keempat, pijakan setelah bermain/recalling yaitu guru dan peserta didik merapikan/mengembalikan mainan yang telah digunakan ke tempatnya, kemudian peserta didik diberikan kesempatan untuk menceritakan kembali pengalaman belajarnya hari itu serta perasaan anak. Peserta didik juga diberikan kesempatan untuk menceritakan hasil karyanya dan menempel pada tempat yang telah ditentukan.

Membantu anak dalam meningkatkan kemampuan konstruksi mereka dari membuat susunan garis lurus ke atas kerepresentasi nyata dan dari bermain sendiri ke kemampuan bekerja dalam kelompok kecil, selanjutnya merencanakan dan membangun. ${ }^{37}$ Sentra balok juga membantu perkembangan anak dalam keterampilan membangun konstruksi seiring dengan pengembangan kemampuan visual-spasial. ${ }^{38}$

\footnotetext{
${ }^{36}$ Suryana, Pendidikan Anak Usia Dini: Stimulasi \& Aspek Perkembangan Anak.

${ }^{37}$ Mukhtar Latif, Orientasi Baru Pendidikan Anak Usia Dini Teori \& Aplikasi (Prenada Media, 2016), 128

${ }^{38}$ Latif, Orientasi Baru Pendidikan Anak Usia Dini Teori \& Aplikasi.
} 
Adapun jenis-jenis dan ukuran balok menurut Frobel yang dikutip Soemarti Patmonodewo yaitu: ${ }^{39}$ yaitu pertama balok blodoos, ukuran alat permainan Frobel yang terdiri dari blodoos dan bouwdoos, bentuknya seperti kotak sebesar 20x20 cm yang berisikan balok-balok kecil berbagai ukuran yang merupakan kelipatan. Kedua balok couuseri. Balok couuseri terdiri atas balok-balok yang berukuran $1 \times 1 \times 1 \mathrm{~cm}$ dengan warna kayu asli, $2 \times 1 \times 1 \mathrm{~cm}$ warna merah, $3 \times 1 \times 1 \mathrm{~cm}$ warna hijau muda, $4 \times 1 \times 1 \mathrm{~cm}$ warna merah muda, $5 \times 1 \times 1 \mathrm{~cm}$ warna kuning, $6 \times 1 \times 1 \mathrm{~cm}$ warna hijau tua, $7 \times 1 \times 1 \mathrm{~cm}$ warna hitam, $8 \times 1 \times 1$ $\mathrm{cm}$ warna coklat, $9 \times 1 \times 1 \mathrm{~cm}$ warna biru tua, $10 \times 1 \times 1 \mathrm{~cm}$ warna jingga.

\section{Kecerdasan Visual-Spasial}

Kecerdasan visual-spasial adalah kecerdasan yang berkaitan dengan kemampuan anak dalam memvisualisasikan gambar di dalam pikiran seseorang atau kemampuan anak berpikir dalam bentuk visual untuk memecahkan suatu masalah atau menemukan jawaban. ${ }^{40}$

Selanjutnya dalam buku Redi Awal Maulana, mendefinisikan kecerdasan visualspasial sebagai kemampuan anak dalam memvisualisasikan apa yang ada dalam benaknya melalui gambar, susunan balok, atau penjelasan yang sangat rinci misalnya mengenai rute ke sekolah. ${ }^{41}$ Hal serupa pun dijelaskan oleh Simanjuntak dengan mendefinisikan kecerdasan visual-spasial sebagai bentuk keahlian yang dapat membedakan secara visual, mengenai bentuk, warna, gambaran mental, dan manipulasi-duplikasi gambar. ${ }^{42}$

Jadi kecerdasan visual-spasial adalah keahlian yang dimiliki seseorang untuk dapat membedakan bentuk, menyusun puzzle, memiliki kepekaan terhadap warna, garis-garis, bentuk-bentuk, dan bangunan-bangunan. Bangunan yang dirancang arsitektur, desain taman, lukisan, rancangan busana, pahatan bahkan benda-benda sehari-hari yang dipakai manusia pun merupakan hasil dari karya orang yang memiliki kecerdasan visual-spasial. Memvisualisasikan apa yang ada dalam pikirannya melalui gambar, susunan balok, atau penjelasan yang sangat rinci misalnya mengenai rute ke sekolah.

Kecerdasan visual-spasial merupakan salah kecerdasan dari sembilan kecerdasan yang dimiliki manusia yang sudah ada sejak lahir, dan perlu dikembangkan. Hal yang dapat dilakukan yaitu melatih anak untuk belajar dengan melibatkan anak dalam hal ikut mengatur ruang rumah, khususnya dalam hal menata kamar tidurnya. Kegiatan ini juga dapat meningkatkan kemandirian pada anak. Mengenalkan arah, agar lebih mudah diingat anak arah yang dapat dikenalkan pada anak arah dari rumah ke sekolah. Hal ini dapat mengembangkan imajinasi anak pada saat membayangkan jalan yang hampir setiap hari dilaluinya. Selain itu, belajar mengamati hal-hal yang terjadi di lingkungan sekitar anak juga dapat mengembangkan imajinasi.

Manfaat kecerdasan visual-spasial bagi seseorang, di antaranya bisa digunakan untuk menciptakan karya seni yang bervariasi dan unik, memecahkan berbagai masalah dan

\footnotetext{
${ }^{39}$ Ibid.

${ }^{40}$ Ndari and Chandrawaty, "Telaah Kurikulum Pendidikan Anak Usia Dini," 195.

${ }^{41}$ Redi Awal Maulana, Math Untuk Anak Usia Dini (Sumedang, 2002), 40.

${ }^{42}$ P.N.H Simanjutak, Pendidikan Kewarganegaraan.
} 
memunculkan berbagai ide baru karena terbantu oleh kemampuan berimajinasi yang tinggi, merancang serta membangun sesuatu seperti gedung atau bangunan lainnya. ${ }^{43}$ Pada individu-individu seperti Leonardo Da Vinci, inteligensi visual-spasial memanifestasikan karya-karya seni yang luar biasa. selain itu Newton yang memvisualisasikan alam sebagai kumpulan semacam mesin dari bagian-bagian yang saling terkait, ini jelas berada di dalam gambaran batin (inner), yang hampir tidak kelihatan. ${ }^{44}$

\section{Kesimpulan}

Kecerdasan visual-spasial adalah kemampuan anak dalam memvisualisasikan apa yang ada dalam benaknya melalui gambar, susunan balok, atau penjelasan yang sangat rinci misalnya mengenai rute ke sekolah. Kemampuan ini memungkinkan untuk mempresentasikan gambaran visual-spasial secara detail dan apa yang dipikirkan dapat dibayangkan dalam bentuk penggambaran dalam benak pikirannya kemudian dituangkan dalam bentuk visual.

Bentuk visual yang dimaksudkan misalnya membuat bangunan dari balok sesuai dengan imajinasinya seperti rumah, istana, jembatan, jalan raya, kolam dan bentuk-bentuk lainnya. Sehingga balok yang merupakan potongan-potongan geometri menjadi sebuah bentuk yang memiliki makna. Dengan cara guru mengenalkan bentuk-bentuk balok serta ukuran besar/kecil balok, guru memberikan contoh pada bangunan yang komplit dalam bentuk gambar. Hal tersebut ditandai dengan kemampuan visual-spasial anak sehingga anak dapat membayangkan suatu bangunan yang sudah ditentukan, dan anak menuangkan dalam bentuk gambar bangunan yang telah dibuatnya sesuai dengan imajinasinya.

Anak yang cerdas secara visual-spasial memiliki kelebihan seperti: anak cepat memahami penjelasan dari guru yang berhubungan dengan bangunan yang akan dibuat, anak dapat melakukan lebih dari perintah guru, anak dapat memadukan warna dengan baik, anak membangun dengan indah, rapi dan bervariasi dan anak senang melakukan serta menikmati bermain balok. Berdasarkan teori diatas dapat disimpulkan bahwa kecerdasan visual-spasial pada anak usia 5-6 tahun dapat ditingkatkan melalui sentra balok. Untuk meningkatkan kecerdasan visual-spasial melalui sentra balok dilakukan dengan empat pijakan yaitu pijakan lingkungan main, pijakan sebelum main, pijakan saat main dan pijakan setelah main.

${ }^{43}$ Ivy Maya Savitri, Montessori for Multiple Intelligences (Bentang Pustaka, 2019), 7.

${ }^{44}$ Linda Campbell, Bruce Campbell, and Dee Dickinson, "Multiple Intelligences: Metode Terbaru Melesatkan Kecerdasan,” Alih Bahasa: Tim Inisiasi). Depok: Inisiasi Pers (2002): 108. 


\section{Daftar Pustaka}

Aisyah, Siti, and others. "Perkembangan Dan Konsep Dasar Pengembangan Anak Usia Dini." Jakarta: universitas terbuka (2008).

Aryani, Nini, M S Mudjiran, M Pd Rakimahwati, and others. MANAJEMEN PEMBELAJARAN PAUD: Berbasis Perkembangan Anak. EDU PUBLISHER, 2020.

Campbell, Linda, Bruce Campbell, and Dee Dickinson. "Multiple Intelligences: Metode Terbaru Melesatkan Kecerdasan.” Alih Bahasa: Tim Inisiasi). Depok: Inisiasi Pers (2002).

Fitriani, Riskia, and Rohita Rohita. "Penanaman Kemandirian Anak Melalui Pembelajaran Di Sentra Balok.” Jurnal Al-Azhar Indonesia Seri Humaniora 5, no. 1 (2019): 290124.

Gunarti, Winda, Lilis Suryani, and Azizah Muis. "Metode Pengembangan Perilaku Dan Kemampuan Dasar Anak Usia Dini." Jakarta: Universitas Terbuka (2008).

Hamzah, A. "Metode Penelitian Kepustakaan Library Research Kajian Filosofis, Aplikasi, Proses, Dan Hasil Penelitian.” Literasi Nusantara (2020).

Hanafi, M Zakaria. Implementasi Metode Sentra Dalam Pengembangan Kecerdasan Majemuk Anak Usia Dini. Deepublish, 2019.

Harianti, Deasy. Metode Jitu Meningkatkan Daya Ingat (Memory Power). Tangga Pustaka, 2008.

Herminayu, and Bambang Suteng Sulasmono. Modul Pelatihan Model Pembelajaran BCCT. Salatiga: UKSW, 2020.

Indonesia, Kamus Besar Bahasa, and Mengenal Operasional Perbankan. "Jakarta: Penerbit PT Gramedia Pustaka Utama" (2014).

Jamaris, Martini. "Pengukuran Kecerdasan Jamak.” Bogor: Ghalia Indonesia (2017).

Kasali, Rhenald. Sentra: Membangun Kecerdasan Dan Kemampuan Anak Sejak Usia Dini, Demi Masa Depan Yang Cemerlang. Mizan, 2019.

Keriapy, Frets. "Pendidikan Kristiani Transformatif Berbasis Multikultural Dalam Konteks Indonesia." REGULA FIDEI: Jurnal Pendidikan Agama Kristen 5, no. 2 (2020): 8293.

Latif, Mukhtar. Orientasi Baru Pendidikan Anak Usia Dini Teori \& Aplikasi. Prenada Media, 2016.

Maulana, Redi Awal. Anak Usia Dini Math: Untuk PAUD. Vol. 1. IGI PD. Sumedang, 2019.

Musfiroh, Tadkiroatun. "Bermain Sambil Belajar Dan Mengasah Kecerdasan.” Jakarta: Depdiknas (2005).

_. "Hakikat Kecerdasan Majemuk (Multiple Intelligences)." Modul Perkuliahan pdf, Universitas Terbuka (2014).

Ndari, Susianty Selaras, and Chandrawaty Chandrawaty. "Telaah Kurikulum Pendidikan Anak Usia Dini." Edu Publisher, n.d.

P.N.H Simanjutak. Pendidikan Kewarganegaraan. Jakarta, 2017.

PERTIWI, PUPUT HANA, and UBAIDILLAH KHASAN. "IMPLEMENTASI PEMBELAJARAN SENTRA BALOK DALAM PENGEMBANGAN MOTORIK HALUS ANAK USIA 4-5 TAHUN DI TK AISYIYAH PUCANGAN 1 KARTASURA TAHUN AJARAN 2019/2020.” IAIN SURAKARTA, 2020.

Redi Awal Maulana. Math Untuk Anak Usia Dini. Sumedang, 2002.

Romini, Romini, and Ida Destariana Harefa. "MANFAAT PENGGUNAAN ALKITAB BERGAMBAR TERHADAP PERKEMBANGAN KEROHANIAN ANAK FUTURE CENTER USIA 7-9 TAHUN DI BULUH AWAR.” EDULEAD: Journal of 
Christian Education and Leadership 1, no. 1 (2020): 1-14.

Savitri, Ivy Maya. Montessori for Multiple Intelligences. Bentang Pustaka, 2019.

Sudono, Anggani. Sumber Belajar Dan Alat Permainan Untuk Pendidikan Anak Usia Dini. Grasindo, 2000.

Suparlan Suhartono. Filsafat Pendidikan. Jogjakarta, 2007.

Suprihatin, Eny, and Desti Rosita. "PENERAPAN TEKNIK SCAFFOLDING SEBAGAI UPAYA MENINGKATKAN KEMANDIRIAN BELAJAR ANAK USIA 5-6 TAHUN DI TK KRISTEN KADASITURU TERPADU." EDULEAD: Journal of Christian Education and Leadership 1, no. 1 (2020): 34-55.

Suryana, Dadan. Pendidikan Anak Usia Dini: Stimulasi \& Aspek Perkembangan Anak. Prenada Media, 2016.

Wahyuni, and Ratna Wahyu Pusari. , Upaya Meningkatkan Kemampuan Visual-Spasial Anak Melalui Bermain Di Sentra Balok Pada Kelompok A TK Himawari Semarang. Semarang: Universitas PGRI, 2015.

Walujo, Djoko Adi, and Anies Listyowati. Kompendium PAUD: Memahami PAUD Secara Singkat. Kencana, 2016.

"Kb Tkwonorejo.Khadijah.or.Id/Sentra-Balok/ Diakses Tanggal 30 Juli 2020, Pukul 07.11.”(n.d.). 